\title{
24-epibrassinolide stimulates imidacloprid detoxification by modulating the gene expression of Brassica juncea $\mathrm{L}$
}

\author{
Anket Sharma ${ }^{1 *}$ D, Sharad Thakur², Vinod Kumar ${ }^{1}$, Anup Kumar Kesavan², Ashwani Kumar Thukral ${ }^{1}$ \\ and Renu Bhardwaj ${ }^{* *}$
}

\begin{abstract}
Background: Pesticides cause oxidative stress to plants and their residues persist in plant parts, which are a major concern for the environment as well as human health. Brassinosteroids (BRs) are known to protect plants from abiotic stress conditions including pesticide toxicity. The present study demonstrated the effects of seed-soaking with 24-epibrassinolide (EBR) on physiological responses of 10-day old Brassica juncea seedlings grown under imidacloprid (IMI) toxicity.
\end{abstract}

Results: In the seedlings raised from EBR-treated seeds and grown under IMI toxicity, the contents of hydrogen peroxide $\left(\mathrm{H}_{2} \mathrm{O}_{2}\right)$ and superoxide anion $\left(\mathrm{O}_{2}^{-}\right)$were decreased, accompanied by enhanced activities of superoxide dismutase (SOD), catalase (CAT), glutathione reductase (GR), glutathione-S-transferase (GST), guaiacol peroxidase (POD) and the content of glutathione (GSH). As compared to controls, the gene expressions of SOD, CAT, GR, POD, NADH (NADH-ubiquinone oxidoreductase), CXE (carboxylesterase), GSH-S (glutathione synthase), GSH-T (glutathione transporter-1), P450 (cytochrome P450 monooxygenase) and GST1-3,5-6 were enhanced in the seedlings raised from EBR-treated seeds and grown in IMI supplemented substratum. However, expression of RBO (respiratory burst oxidase, the gene responsible for $\mathrm{H}_{2} \mathrm{O}_{2}$ production) was decreased in seedlings raised from EBR treated seeds and grown under IMI toxicity. Further, the EBR seed treatment decreased IMI residues by more than $38 \%$ in B. juncea seedlings.

Conclusions: The present study revealed that EBR seed soaking can efficiently reduce oxidative stress and IMI residues by modulating the gene expression of B. juncea under IMI stress. In conclusion, exogenous EBR application can protect plants from pesticide phytotoxicity.

Keywords: Brassica juncea, Imidacloprid toxicity, Brassinosteroids, Pesticide residues

\section{Background}

Plants are susceptible to attack by various insect pests like termites, soil bugs, aphids and leaf hoppers. Pesticides are widely utilized to control these insect pests, but these pesticides cause aerial pollution upon spraying due to their volatile nature [1]. Imidacloprid (IMI) is a neonicotinoid insecticide, which is systemic in action and applied via soil/seed treatment to protect plants from soil and aerial insect pests, without causing any aerial pesticide pollution [2]. Application of pesticides causes oxidative stress to plants by generating reactive oxygen species [3, 4].

\footnotetext{
* Correspondence: anketsharma@gmail.com; renubhardwaj82@gmail.com

${ }^{1}$ Plant Stress Physiology Lab, Department of Botanical and Environmental

Sciences, Guru Nanak Dev University, Amritsar, India143005

Full list of author information is available at the end of the article
}

Pesticides persist in the parts of plants in form of pesticide residues $[4,5]$ which cause a major threat to humans as well as pollinators, including honeybees [6]. Due to their persistence in form of residues, pesticides also enter the ecosystem via the food chain, hence cause serious threat to ecosystems and the environment [1]. Plants are able to degrade pesticides into soluble and less toxic metabolites through a three-phased enzyme-mediated degradation process $[7,8]$. The first phase involves enzymes like cytochrome P450 monooxygenases (P450), peroxidases and carboxylesterases, which are involved in the activation of pesticides. In the $2^{\text {nd }}$ phase, glutathione-S-transferase (GST) and UDP-glycosyltransferase help in the conjugation of activated pesticides with glutathione (GSH) and 
glucose, resulting in the formation of less toxic and more soluble metabolites. These metabolites are finally stored in vacuoles or in the apoplast in the $3^{\text {rd }}$ phase of pesticide detoxification. Brassinosteroids (BRs), a class of plant hormones, are well known to protect plants from abiotic stresses including that caused by the pesticides [9-12]. BRs also decrease oxidative stress in plants caused by pesticides, accompanied by enhanced activities of antioxidative enzymes [3] and a decrease of pesticide residues in plants [5, 6]. Exogenous application of BRs have been reported to enhance the expression of genes encoding P450, GST, superoxide dismutase (SOD), ascorbate peroxidase (APOX), catalase (CAT), glutathione reductase (GR) and GSH synthase, resulting in pesticide detoxification $[3,5]$. Pesticide application causes oxidative stress to plants by producing reactive oxygen species (ROS), and persists in the form of pesticide residues. Antioxidative and pesticide detoxification enzymes help in scavenging ROS and reduction of pesticide residues. Keeping in mind the roles of BRs in boosting the antioxidative defence system of plants under pesticide toxicity, the present work was carried out to understand the 24-epibrassinolide (EBR)-regulated pesticide detoxification mechanism in Brassica juncea seedlings. In earlier studies, researchers have mostly applied BRs via foliar mode, but the present study was undertaken to access the effects of seed-soaking with EBR on oxidative stress and IMI residues in 10-day old $B$. juncea seedlings grown under IMI toxicity.

\section{Methods}

\section{Plant germination}

Seeds of $B$. juncea L. variety RLC-1 were soaked in 0 or $100 \mathrm{nM} \mathrm{EBR} \mathrm{L^{-1 }}$ for $8 \mathrm{~h}$. IMI concentrations $(0,150$, 200 and $250 \mathrm{mg} \mathrm{IMI} \mathrm{L}^{-1}$ ) were prepared by dissolving IMI in distilled water. $3 \mathrm{~mL}$ of IMI solution were poured into each Petri-plate lined with Whatman\#1 filter-paper. The EBR-soaked seeds of $B$. juncea were germinated in Petri-plates containing IMI solutions and kept in a seed germinator $\left(25 \pm 0.5{ }^{\circ} \mathrm{C}\right.$ temperature, $16 \mathrm{~h}$ photoperiod, and $175 \mu \mathrm{mol} \mathrm{m} \mathrm{m}^{-2} \mathrm{~s}^{-1}$ light intensity). Seedlings were harvested after 10 days of sowing and analysed for contents of ROS and GSH, the activities of antioxidative enzymes, expression of genes and IMI residues. All the experiments were performed in triplicates. Each replicate consisted of one Petri-plate, and 10 seedlings were randomly selected from it.

\section{Estimation of reactive oxygen species Superoxide anions $\left(\mathrm{O}_{2}^{-}\right)$}

The superoxide anion content was estimated according to $\mathrm{Wu}$ et al. [13]. One g of plant tissue was homogenized in $6 \mathrm{~mL}$ of phosphate buffer $(65 \mathrm{mM}, \mathrm{pH}=7.8)$ containing $1 \%$ of polyvinylpyrrolidone. The homogenate was centrifuged at $5000 \times \mathrm{g}$ for $15 \mathrm{~min}$ at $4{ }^{\circ} \mathrm{C}$. To $0.5 \mathrm{~mL}$ of supernatant,
$0.5 \mathrm{~mL}$ of phosphate buffer $(65 \mathrm{mM}, \mathrm{pH}=7.8)$ and $0.1 \mathrm{~mL}$ of hydroxylamine hydrochloride $(10 \mathrm{mM})$ were added. The mixture was incubated at $25{ }^{\circ} \mathrm{C}$ for $30 \mathrm{~min}$. After incubation, $1 \mathrm{~mL}$ of 3-aminobenzenesulphonic acid $(58 \mathrm{mM})$ and $1 \mathrm{~mL}$ of 1-naphthylamine $(7 \mathrm{mM})$ were added to the mixture, followed by an incubation at $25{ }^{\circ} \mathrm{C}$ for $20 \mathrm{~min}$. The absorbance was measured at $530 \mathrm{~nm}$. To calculate the superoxide content, a standard curve of sodium nitrite was used and content was expressed as $\mu \mathrm{mol} \mathrm{g}^{-1} \mathrm{FW}$ of seedlings.

\section{Hydrogen peroxide $\left(\mathrm{H}_{2} \mathrm{O}_{2}\right)$}

$\mathrm{H}_{2} \mathrm{O}_{2}$ was evaluated using method given by Patterson et al. [14]. Plant tissue $(0.5 \mathrm{~g})$ was crushed in $1 \mathrm{~mL}$ of acetone, followed by centrifugation at $5000 \times \mathrm{g}$ for $15 \mathrm{~min}$ at $4{ }^{\circ} \mathrm{C}$. To the supernatant, $20 \mu \mathrm{L}$ of $20 \%$ titanium chloride in concentrated $\mathrm{HCl}$ were added. Then $200 \mu \mathrm{L}$ of ammonia solution $(17 \mathrm{M})$ were added, followed by repeated washing of the precipitate with acetone. Washed precipitates were dissolved in $1.5 \mathrm{~mL}$ of $\mathrm{H}_{2} \mathrm{SO}_{4}(2 \mathrm{~N})$. Absorbance was read at $410 \mathrm{~nm}$. The content of hydrogen peroxide was calculated from a standard curve of $\mathrm{H}_{2} \mathrm{O}_{2}$ and was expressed as $\mu \mathrm{mol} \mathrm{g}{ }^{-1} \mathrm{FW}$ of seedlings.

\section{Estimation of antioxidative enzymes and glutathione content \\ Superoxide dismutase (SOD)}

SOD activity was estimated according to Kono [15] with minor modifications. One $\mathrm{g}$ of plant tissue was homogenized in $3 \mathrm{~mL}$ of sodium carbonate buffer, followed by centrifugation at $12,000 \times \mathrm{g}$ at $4{ }^{\circ} \mathrm{C}$ for $20 \mathrm{~min}$. Supernatant was used as sample for further analysis. The reaction mixture consisted of $1630 \mu \mathrm{L}$ of sodium carbonate buffer $(\mathrm{pH}=10.2), 500 \mu \mathrm{L}$ of nitroblue tetrazolium $(24 \mu \mathrm{M})$, $100 \mu \mathrm{L}$ of EDTA $(0.1 \mathrm{mM}), 100 \mu \mathrm{L}$ of hydroxylamine hydrochloride (1 mM), $100 \mu \mathrm{L}$ of Triton-X-100 (0.03\%) and $70 \mu \mathrm{L}$ of sample. The absorbance was measured at $560 \mathrm{~nm}$.

\section{Catalase (CAT)}

CAT activity was estimated according to Aebi [16] with slight modifications. $3 \mathrm{~mL}$ of $100 \mathrm{mM}$ potassium phosphate buffer (PPB) with $\mathrm{pH} 7.0$ were used for homogenization of $1 \mathrm{~g}$ of fresh seedlings. The homogenate was then centrifuged at $2000 \times \mathrm{g}$ for $20 \mathrm{~min}$ at $4{ }^{\circ} \mathrm{C}$, and the supernatant was used to estimate the CAT activity. In a cuvette, the reaction mixture consisted of $1500 \mu \mathrm{L}$ of $\mathrm{PPB}(\mathrm{pH}=7.0,50 \mathrm{mM}), 930 \mu \mathrm{L}$ of hydrogen peroxide $(15 \mathrm{mM})$ and $70 \mu \mathrm{L}$ of sample. The absorbance was measured at $240 \mathrm{~nm}$.

\section{Guaiacol peroxidase (POD)}

The activity of POD was determined using method given by Putter [17]. One $g$ of seedlings was homogenized in $3 \mathrm{~mL}$ of $\mathrm{PPB}(100 \mathrm{mM}, \mathrm{pH}=7.0)$ buffer, followed by 
centrifugation at $12,000 \times \mathrm{g}$ at $4{ }^{\circ} \mathrm{C}$ for $20 \mathrm{~min}$. The supernatant was used as sample for further analysis. The absorbance was recorded at $436 \mathrm{~nm}$ by preparing a reaction mixture containing $70 \mu \mathrm{L}$ sample with $2350 \mu \mathrm{L} \mathrm{PPB}$ (50 mM, pH 7.0), $50 \mu \mathrm{L}$ guaiacol solution $(20 \mathrm{mM})$ and $30 \mu \mathrm{L} \mathrm{H} 2 \mathrm{O} 2(12 \mathrm{mM})$.

\section{Glutathione reductase (GR)}

GR activity was determined according to Carlberg and Mannervik [18]. One $g$ of fresh seedlings was homogenized in $3 \mathrm{~mL}$ of PPB $(100 \mathrm{mM}, \mathrm{pH}=7.0)$ buffer followed by centrifugation at $12,000 \times \mathrm{g}$ at $4{ }^{\circ} \mathrm{C}$ for $20 \mathrm{~min}$. The supernatant was used as plant sample to determine GR activity. The reaction mixture contained $1530 \mu \mathrm{L} \mathrm{PPB}$ (50 mM, pH 7.0), $300 \mu \mathrm{L}$ each of ethylenediaminetetraacetate (EDTA) $(3.0 \mathrm{mM}), \mathrm{NADPH}(0.1 \mathrm{mM})$, oxidized glutathione $(1.0 \mathrm{M})$, and $70 \mu \mathrm{L}$ sample. The absorbance was recorded at $340 \mathrm{~nm}$.

\section{Glutathione-S-transferase (GST)}

The glutathione-S-transferase activity was quantified based on Habig and Jacoby [19]. One g of fresh seedlings was homogenized in $3 \mathrm{~mL}$ of PPB $(100 \mathrm{mM}, \mathrm{pH}=7.5)$ buffer and centrifuged at $12,000 \times \mathrm{g}$ at $4{ }^{\circ} \mathrm{C}$ for $20 \mathrm{~min}$. The supernatant was used as sample in reaction mixture. The reaction mixture contained $70 \mu \mathrm{L}$ sample, $1930 \mu \mathrm{L}$ PPB (50 mM, pH 7.5), and $250 \mu \mathrm{L}$ each of reduced glutathione $(10 \mathrm{mM})$ and 1-chloro-2,4-dinitrobenzene $(10 \mathrm{mM})$. The absorbance was measured at $340 \mathrm{~nm}$.

\section{Glutathione (GSH)}

The glutathione content was determined according to the scheme given by Sedlak and Lindsay [20]. Fresh plant tissue $(1 \mathrm{~g})$ was homogenized in $3 \mathrm{~mL}$ of Tris buffer (50 mM, pH 10.0) containing $1 \mathrm{mM}$ EDTA. The homogenate was then subjected to centrifugation at $12,000 \times \mathrm{g}$ for $15 \mathrm{~min}$, and the supernatant from the plant extract was used to estimate the GSH content. To the $100 \mu \mathrm{L}$ of plant extract, $1 \mathrm{~mL}$ of Tris buffer, $50 \mu \mathrm{L}$ of Ellman's reagent and $4 \mathrm{~mL}$ of absolute methanol were added, and kept at room temperature for $15 \mathrm{~min}$ and then subjected to centrifugation at $3000 \times \mathrm{g}$ for $15 \mathrm{~min}$. The absorbance of the supernatant was measured noted at $412 \mathrm{~nm}$.

\section{Gene expression analysis}

Total RNA was extracted from whole seedlings using Trizol method according to the manufacturer's instructions (Invitrogen). Total RNA was used for reverse transcription with an RNA to cDNA kit (Invitrogen), containing MuLV as reverse transcriptase, dNTP's mix, random octamers and oligo $(\mathrm{dT})_{16}$. Gene-specific primers (Table 1) were designed according to the mRNA sequence from Genbank and EMBL database, and the actin gene was used as an internal control due to its
Table 1 Primers used for quantitative real time polymerase chain reaction ( $q R T-P C R$ )

\begin{tabular}{|c|c|}
\hline Gene name & Primer sequence \\
\hline actin & $\begin{array}{l}\text { Forward primer 5' CTTGCACCTAGCAGCATGAA 3' } \\
\text { Reverse primer 5' GGACAATGGATGGACCTGAC 3' }\end{array}$ \\
\hline SOD & $\begin{array}{l}\text { Forward primer 5'GGTTCCATGTCCATGCTCT 3' } \\
\text { Reverse primer 5'ATTGTGAAGGTGGCAGTTCC 3' }\end{array}$ \\
\hline CAT & $\begin{array}{l}\text { Forward primer 5' TCAGCTGCCAGTTAATGCAC 3' } \\
\text { Reverse primer 5' GACAGCAGGTGGAGTTGGAT 3' }\end{array}$ \\
\hline$G R$ & $\begin{array}{l}\text { Forward primer 5' AAGGCAAAAGAAGGTGCTGA 3' } \\
\text { Reverse primer 5' AGTTCCCTTGCTGGTCTTCA 3' }\end{array}$ \\
\hline $\mathrm{RBOH}$ & $\begin{array}{l}\text { Forward primer 5'ACGGGGTGTGATAGAGATGC 3' } \\
\text { Reverse primer 5'TITITCCAGTTGGGTCTTGC 3' }\end{array}$ \\
\hline $\mathrm{NADH}$ & $\begin{array}{l}\text { Forward primer 5'CTCGGCCTTCTCAACAGAC 3' } \\
\text { Reverse primer 5'CATTCCCAAGTITCCCAGA 3' }\end{array}$ \\
\hline CXE & $\begin{array}{l}\text { Forward primer 5' GGCGCTAACATGACTCATCA 3' } \\
\text { Reverse primer 5' CTCCCAGAGTTGAGCGATTC 3' }\end{array}$ \\
\hline GSH-S & $\begin{array}{l}\text { Forward primer 5' CCCATCTTCAACGAGTTGGT 3' } \\
\text { Reverse primer 5' GTGCAAACCCAAACGAATCT 3' }\end{array}$ \\
\hline GSH-T & $\begin{array}{l}\text { Forward primer 5'GCTGGTCACAGGAACCATCT 3' } \\
\text { Reverse primer 5'CTACTTCAGTGCCCCACCAT 3' }\end{array}$ \\
\hline GST-1 & $\begin{array}{l}\text { Forward primer 5'CGTCGTCGAAGAAGAAGAGG 3' } \\
\text { Reverse primer 5'TTITGGTGGGAGTTCCAAG 3' }\end{array}$ \\
\hline GST-2 & $\begin{array}{l}\text { Forward primer 5'AGACCAAGCCGTTGTTGAAG 3' } \\
\text { Reverse primer 5'TाTाTGGTGGGAGTTCCAAG 3' }\end{array}$ \\
\hline GST-3 & $\begin{array}{l}\text { Forward primer 5'TACGAGGCTAGGCTCAAGGA 3' } \\
\text { Reverse primer 5'AGCCACCCACTCGTTAACAC 3' }\end{array}$ \\
\hline GST-4 & $\begin{array}{l}\text { Forward primer 5'CAAGGAACCAACCTTCTCCA 3' } \\
\text { Reverse primer 5'TGGTCAGTGGTCAAGCCATA 3' }\end{array}$ \\
\hline GST-5 & $\begin{array}{l}\text { Forward primer 5'AGTGGCTGCAAAGCTTGTTा 3' } \\
\text { Reverse primer 5'TGTGGTGAAGATCGGTCAAA 3' }\end{array}$ \\
\hline GST-6 & $\begin{array}{l}\text { Forward primer 5'GCCGAAGAGGAGGCTAAGTT 3' } \\
\text { Reverse primer 5'TCGGTGAAGAGCTTCTTGGT 3' }\end{array}$ \\
\hline$P O D$ & $\begin{array}{l}\text { Forward primer 5' TTCGAACGGAAAAAGATGCT 3' } \\
\text { Reverse primer 5' AACCCTCCATGAAGGACCTC 3' }\end{array}$ \\
\hline P450 & $\begin{array}{l}\text { Forward primer 5' CATTTGTTCTCACCCACACG 3' } \\
\text { Reverse primer 5' CACAACCGAGTTCGTGAATG 3' }\end{array}$ \\
\hline
\end{tabular}

high expression stability in the vegetative stage of plants. Quantitative real time PCR (qRT-PCR) was performed using the StepOne ${ }^{\mathrm{in}}$ real time detection system (Applied Biosystems) and Power SYBR ${ }^{\circ}$ Green PCR Master Mix (three biological and technical replicates). A melting curve was generated at the end of the each PCR cycle, which verified that a single product was amplified, using the software provided along with the PCR system. The mRNA quantification was based on the method of Livak and Schmittgen [21]. $\Delta \mathrm{Ct}$ values were obtained by subtracting the threshold value $(\mathrm{Ct})$ of the internal control (actin) from that of the gene of interest. $\Delta \Delta \mathrm{Ct}$ values were obtained by subtracting the $\mathrm{Ct}$ values of the untreated control sample from the $\Delta \mathrm{Ct}$ value. The fold-changes in the expression levels relative to the untreated samples were expressed as $2^{-\Delta \Delta C t}$. 


\section{Analysis of IMI residues}

AOAC, the official method 2007.01 [22] was followed to prepare seedling extracts for IMI residue analysis. One $g$ of seedlings was crushed in $1 \mathrm{~mL} 1 \%$ acetic acid in acetonitrile, and $200 \mathrm{mg}$ of anhydrous $\mathrm{MgSO}_{4}$ and $50 \mathrm{mg}$ sodium acetate were added. The mixture was shaken for $2 \mathrm{~min}$, followed by centrifugation at $1500 \times \mathrm{g}$ for $5 \mathrm{~min}$. $0.5 \mathrm{~mL}$ of the upper layer was taken, and $75 \mathrm{mg}$ anhydrous $\mathrm{MgSO}_{4}$ along with $25 \mathrm{mg}$ of primary secondary amine (PSA) sorbent were added. The mixture was again centrifuged, followed by filtration of the upper layer with $0.22 \mu$ filters and stored at $4{ }^{\circ} \mathrm{C}$ until analysis.

\section{GC-MS analysis}

GC-MS (QP2010 Plus, Shimadzu, Kyoto, Japan) was used to analyse the seedling extracts for IMI residues. Helium was used as carrier gas, the initial oven column temperature was set at $50{ }^{\circ} \mathrm{C}$, followed by increasing it to $125^{\circ} \mathrm{C}$ at $25{ }^{\circ} \mathrm{C} \min ^{-1}$ and finally increased to $300{ }^{\circ} \mathrm{C}$ at $10{ }^{\circ} \mathrm{C} \mathrm{min}{ }^{-1}$ (hold for $15 \mathrm{~min}$ ). The sample injector temperature was set to $250{ }^{\circ} \mathrm{C}$, the injection mode was split, column flow rate was $1.70 \mathrm{~mL} \mathrm{~min}^{-1}$, the analytical column used was DB- 5 ms. The ion source and interface temperatures were set to $200{ }^{\circ} \mathrm{C}$ and $280{ }^{\circ} \mathrm{C}$ respectively. The volume of the sample injected was $8 \mu \mathrm{L}$.

\section{Statistical analysis}

The results were analysed using Two-way ANOVA, Tukey's HSD and multiple linear regression analysis (MLR), using self-coded software (MS-Excel 2010) and artificial neural networks (ANN), using Statistica-12. In ANN model, contents of oxidative stress markers and GSH, activities of antioxidative enzymes, relative expression of genes and IMI residues (targets) were regressed against the concentration of applied IMI and EBR (inputs), using 3 neurons, 1 hidden layer, tanh function from input to neurons, and from neurons to output.

\section{Results}

\section{Effects of EBR on ROS}

Imidacloprid (IMI) application was observed to increase the oxidative stress in $B$. juncea seedlings by enhancing the contents of $\mathrm{H}_{2} \mathrm{O}_{2}$ and $\mathrm{O}_{2}^{-}$. However, seed soaking with $100 \mathrm{nM}$ EBR resulted in decreasing the contents of these reactive oxygen species (ROS) in the seedlings grown in IMI supplemented Petri-plates (Table 2). Statistical analysis of data using two-way ANOVA and Tukey's HSD revealed that there was a significant difference in ROS contents in the seedlings of B. juncea plants. Multiple linear regression (MLR) analysis revealed that the partial regressions between the concentrations of EBR used for seed soaking and the contents of $\mathrm{H}_{2} \mathrm{O}_{2}$ and $\mathrm{O}_{2}^{-}$generated were regressed negatively, whereas IMI regressed positively on the generation of these ROS. This indicated the role of EBR in decreasing the ROS generation (Table 2).

\section{Effects of EBR on Glutathione content and activities of antioxidative enzymes}

The content of GSH as well as the activities of antioxidative enzymes like SOD, CAT, POD, GR and GST were enhanced in the seedlings raised from EBR-treated seeds and grown in Petri-plates supplemented with IMI solutions (Table 2). Significant differences in SOD, CAT, POD, GR and GST activities and GSH content were observed after analysing the data, using two-way ANOVA and Tukey's HSD. MLR analysis and positive $\beta_{\mathrm{EBR}}$ regression coefficients also showed that EBR application increases the GSH content and activities of antioxidative enzymes (Table 2).

\section{Effects of EBR on gene expression}

We observed that seed soaking with EBR significantly modulated the gene expression in $B$. juncea seedlings grown under IMI toxicity (Fig. 1). The fold-change expression of the $R B O$ gene was decreased by $37.65 \%$ in seedlings raised from EBR-treated seed, and grown under IMI toxicity, as compared to seedlings raised from untreated seeds and grown under IMI toxicity. On similar comparison of $B$. juncea seedlings, an increase in the expression of SOD (39.42\%), CAT (78.82\%), GR (23.24\%), POD (31.51\%), GST1 (64.04\%), GST2 (90.51\%), GST3 (157.64\%), GST5 (203.39\%), GST6 (154.76\%), GSH-S (56.52\%), GSH-T (32.0\%), CXE (99.28\%), NADH (18.18\%) and $P 450$ (152.78\%) was noticed (Fig. 1). We observed a significant difference in the expression of genes encoding enzymes involved in pesticide detoxification enzymes in $B$. juncea seedlings after analysing the data using twoway ANOVA and Tukey's HSD. Positive $\beta_{\mathrm{EBR}}$ values obtained from the MLR analysis revealed that EBR seed soaking up-regulated the expression of all the genes (encoding enzymes involved in pesticide detoxification enzymes), except GST-4 (Table 3).

\section{The Effect of EBR on IMI residues}

IMI residues were reduced by $38 \%$ in the seedlings raised from EBR seed soaking and germinated in IMItreated Petri-plates (Fig. 2). The analysis of data using two-way ANOVA and Tukey's HSD showed a significant difference for IMI residues in $B$. juncea seedlings raised from untreated seeds and EBR treated seeds and grown under IMI toxicity. A negative $\beta_{\mathrm{EBR}}$ regression coefficient for IMI residues also revealed that seed soaking with EBR results in decreasing the IMI residues (Table 4).

Our data analysis using ANN also showed that experimental (target) and simulated (output) data were highly 


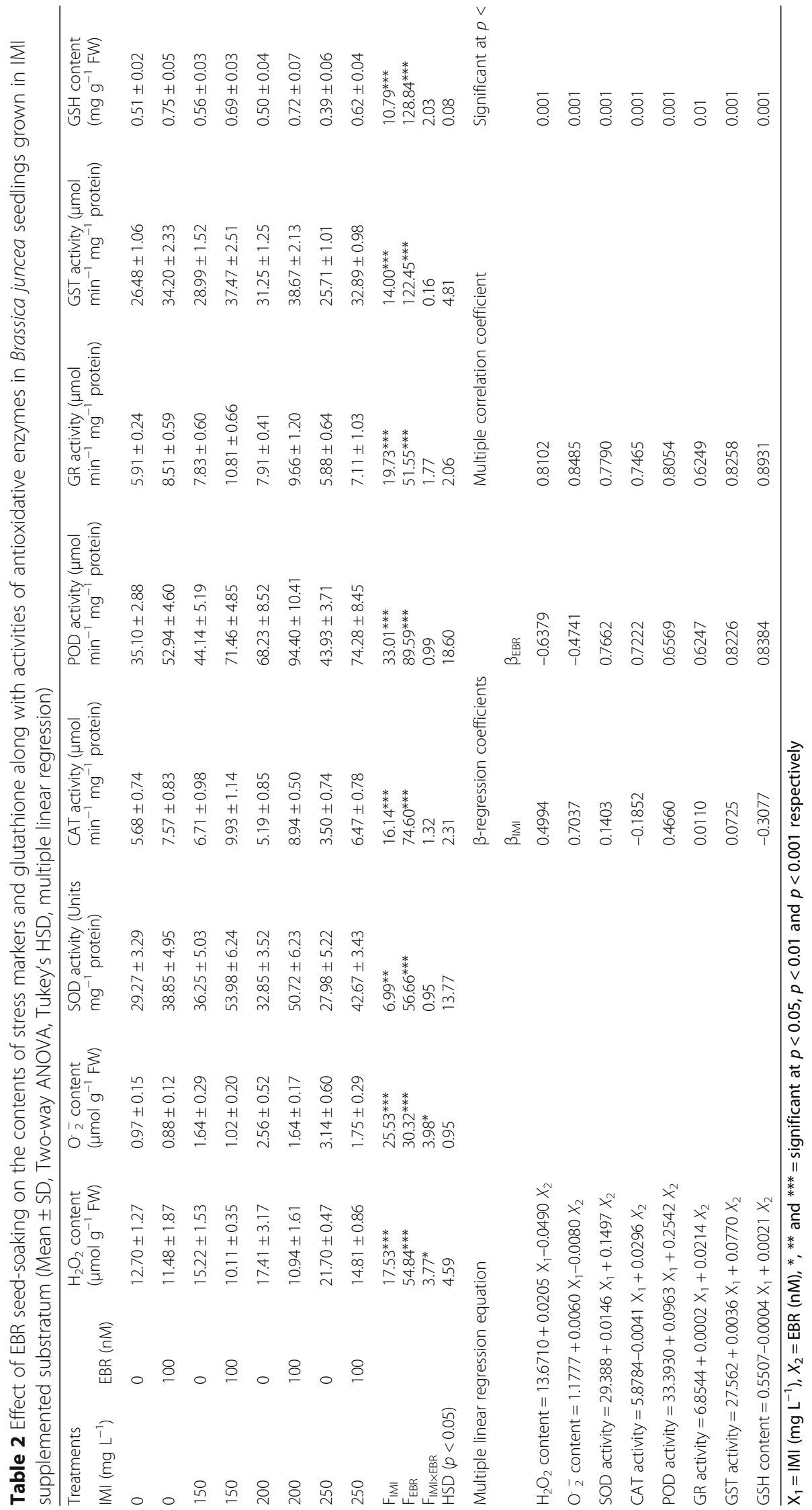



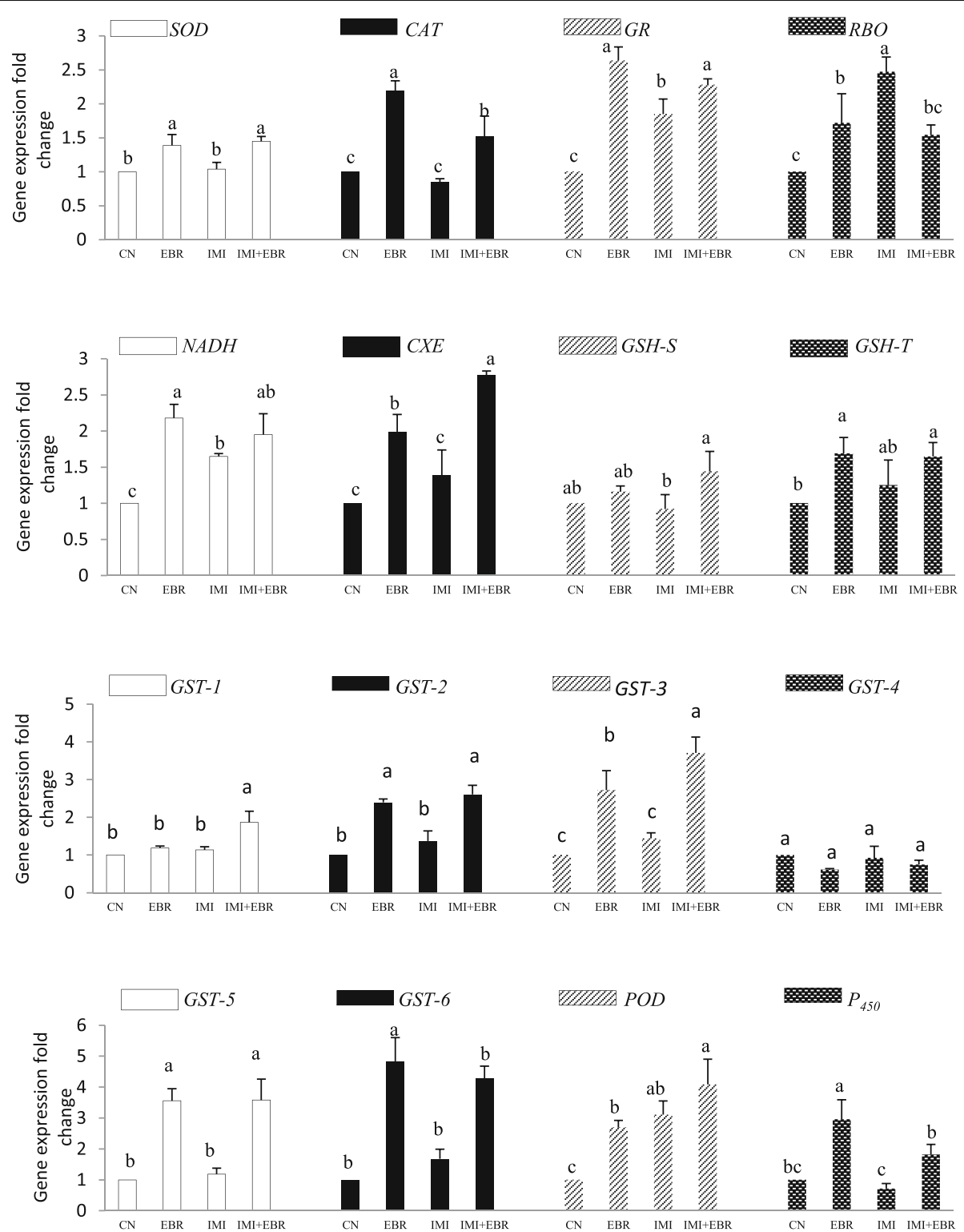

Fig. 1 Effect of EBR seed-soaking on the relative expression of genes involved in IMI stress amelioration in Brassica juncea seedlings. Data are shown as the mean \pm standard deviation (three biological replicates), bars with the same letters indicate no significant difference at $p<0.05$ (comparison among treatments of same gene). HSD values for each gene have been mentioned in Table 3. (EBR concentration $=100 \mathrm{nM}$ and IMI concentration $=200 \mathrm{mg} \mathrm{IMI} \mathrm{L}^{-1}$ )

correlated, which indicates that ANN simulates the physiological studies carried out in the current experiment at a very high level of significance (Table 5).

\section{Discussion}

In the present investigation, the contents of ROS including and $\mathrm{O}_{2}^{-}$and $\mathrm{H}_{2} \mathrm{O}_{2}$ were noticed to increase with the application of IMI. A decrease in the contents of these ROS was noticed after EBR seed treatment. One of the reasons for the production of these ROS might be oxidative burst caused by abiotic stress conditions due to the disruption of the antioxidative defense system [23]. It has also been demonstrated that $\mathrm{RBOH1}$ (Respiratory burst oxidase homologue1) is responsible for the production of $\mathrm{H}_{2} \mathrm{O}_{2}$ in plants under pesticide stress [4]. Moreover, in the current study, we also observed that the expression of the $R B O$ gene (respiratory burst oxidase, a gene which is responsible for the production of $\mathrm{H}_{2} \mathrm{O}_{2}$ ) was up-regulated in $B$. juncea plants grown under IMI toxicity. It has been observed that the $\mathrm{O}_{2}^{-}$content was decreased after seed application of EBR, and it might have occurred as a result of the conversion of $\mathrm{O}_{2}^{-}$ to $\mathrm{H}_{2} \mathrm{O}_{2}$ by superoxide dismutase (SOD), whose activity as well as gene expression (SOD) in the current 
Table 3 Two-way ANOVA and multiple linear regression analysis (MLR) of the relative gene expression in Brassica juncea seedlings raised from EBR-soaked seeds and grown in IMI supplemented substratum

\begin{tabular}{|c|c|c|c|c|}
\hline \multirow[t]{2}{*}{ Gene name } & \multicolumn{3}{|l|}{ F-ratios } & \multirow[t]{2}{*}{ HSD $(p<0.05)$} \\
\hline & $F_{I M I}$ & $\mathrm{~F}_{\mathrm{EBR}}$ & $F_{|M| \times E B R}$ & \\
\hline$S O D$ & 0.78 & $48.57^{* * *}$ & 0.01 & 0.26 \\
\hline CAT & $16.66^{* *}$ & $87.07^{* * *}$ & $6.89^{*}$ & 0.45 \\
\hline$G R$ & $7.05^{*}$ & $124.34^{* * *}$ & $42.83^{* * *}$ & 0.41 \\
\hline $\mathrm{RBOH}$ & $19.06^{* *}$ & 0.46 & $31.10^{* * *}$ & 0.66 \\
\hline $\mathrm{NADH}$ & 4.16 & $51.72^{* * *}$ & $18.29^{* *}$ & 0.46 \\
\hline CXE & $21.64^{* *}$ & $88.35^{* * *}$ & 2.26 & 0.56 \\
\hline GSH-S & 0.93 & $10.57^{*}$ & 2.86 & 0.46 \\
\hline GSH-T & 0.59 & $17.10^{* *}$ & 1.14 & 0.60 \\
\hline GST-1 & $21.14^{* *}$ & $26.40^{* * *}$ & $8.68^{*}$ & 0.40 \\
\hline GST-2 & $6.86^{*}$ & $143.74^{* * *}$ & 0.52 & 0.49 \\
\hline GST-3 & $12.82^{* *}$ & $99.63^{* * *}$ & 1.85 & 0.90 \\
\hline GST-4 & 0.09 & $8.38^{*}$ & 1.07 & 0.43 \\
\hline GST-5 & 0.19 & $110.10^{* * *}$ & 0.11 & 1.06 \\
\hline GST-6 & 0.059 & $143.70^{* * *}$ & 5.28 & 1.21 \\
\hline$P O D$ & $40.71^{* * *}$ & $23.44^{* *}$ & 1.66 & 1.24 \\
\hline P450 & $11.03^{*}$ & $51.62^{* * *}$ & 4.06 & 0.96 \\
\hline \multirow[t]{2}{*}{ MLR equation } & \multicolumn{2}{|c|}{$\beta$-regression coefficient } & Multiple correlation coefficient & Significant at $p<$ \\
\hline & $\beta_{I M I}$ & $\beta_{\mathrm{EBR}}$ & & \\
\hline SOD expression $=0.9960+0.0003 X_{1}+0.0041 X_{2}$ & 0.1169 & 0.9201 & 0.9274 & 0.001 \\
\hline CAT expression $=1.1311-0.0020 X_{1}+0.0093 X_{2}$ & -0.3748 & 0.8566 & 0.9351 & 0.001 \\
\hline$G R$ expression $=1.3034+0.0012 X_{1}+0.0103 X_{2}$ & 0.1968 & 0.8260 & 0.8491 & 0.001 \\
\hline$R B O H$ expression $=1.4136+0.0032 X_{1}-0.0010 X_{2}$ & 0.5702 & -0.0892 & 0.5771 & 0.10 \\
\hline $\mathrm{NADH}$ expression $=1.2212+0.0011 \mathrm{X}_{1}+0.0074 \mathrm{X}_{2}$ & 0.2250 & 0.7933 & 0.8246 & 0.01 \\
\hline CXE expression $=0.9051+0.0029 X_{1}+0.0118 X_{2}$ & 0.4242 & 0.8571 & 0.9563 & 0.001 \\
\hline GSH-S expression $=0.9113+0.0005 X_{1}+0.0034 X_{2}$ & 0.2040 & 0.6875 & 0.7170 & 0.02 \\
\hline GSH-T expression $=1.0713+0.0005 X_{1}+0.0055 X_{2}$ & 0.1483 & 0.7983 & 0.8120 & 0.01 \\
\hline GST-1 expression $=0.8681+0.0021 X_{1}+0.0046 X_{2}$ & 0.5737 & 0.6411 & 0.8604 & 0.001 \\
\hline GST-2 expression $=1.0400+0.0015 X_{1}+0.0133 X_{2}$ & 0.2077 & 0.9504 & 0.9728 & 0.001 \\
\hline GST-3 expression $=0.8635+0.0036 X_{1}+0.0200 X_{2}$ & 0.3238 & 0.9025 & 0.9588 & 0.001 \\
\hline GST-4 expression $=0.9497+0.0002 X_{1}-0.0030 X_{2}$ & 0.0747 & -0.6909 & 0.6949 & 0.02 \\
\hline GST-5 expression $=1.0393+0.0005 X_{1}+0.0248 X_{2}$ & 0.0401 & 0.9643 & 0.9651 & 0.001 \\
\hline GST-6 expression $=1.3087+0.0003 X_{1}+0.0322 X_{2}$ & 0.0195 & 0.9565 & 0.9567 & 0.001 \\
\hline$P O D$ expression $=1.1777+0.0088 X_{1}+0.0134 X_{2}$ & 0.7426 & 0.5635 & 0.9322 & 0.001 \\
\hline$P 450$ expression $=1.2155-0.0036 X_{1}+0.0154 X_{2}$ & -0.3842 & 0.8312 & 0.9157 & 0.001 \\
\hline
\end{tabular}

$\mathrm{X}_{1}=\mathrm{IMI}\left(\mathrm{mg} \mathrm{L}^{-1}\right), X_{2}=\mathrm{EBR}(\mathrm{nM}),{ }^{*},{ }^{* *}$ and ${ }^{* * *}=$ significant at $p<0.05, p<0.01$ and $p<0.001$ respectively

experiment was also observed to be enhanced after the seed treatment of EBR. Additionally, the content of $\mathrm{H}_{2} \mathrm{O}_{2}$ was also noticed to decline with seed application of EBR, and the possible reason behind this could be the conversion of $\mathrm{H}_{2} \mathrm{O}_{2}$ to water and molecular oxygen by the antioxidative enzyme catalase (CAT). In the current study, the activity of the CAT enzyme and the expression of the CAT gene were also increased in seedlings raised from EBR-soaked seeds and grown in Petri-plates containing IMI. Moreover, the expression of $R B O$ has also been observed to decrease with the EBR application, suggesting another reason for the significant reduction of $\mathrm{H}_{2} \mathrm{O}_{2}$. Studies carried out by Hayat et al. [24] and Fariduddin et al. [25] also showed that BRs play an important role in the scavenging of ROS in plants under environmental stress conditions. 


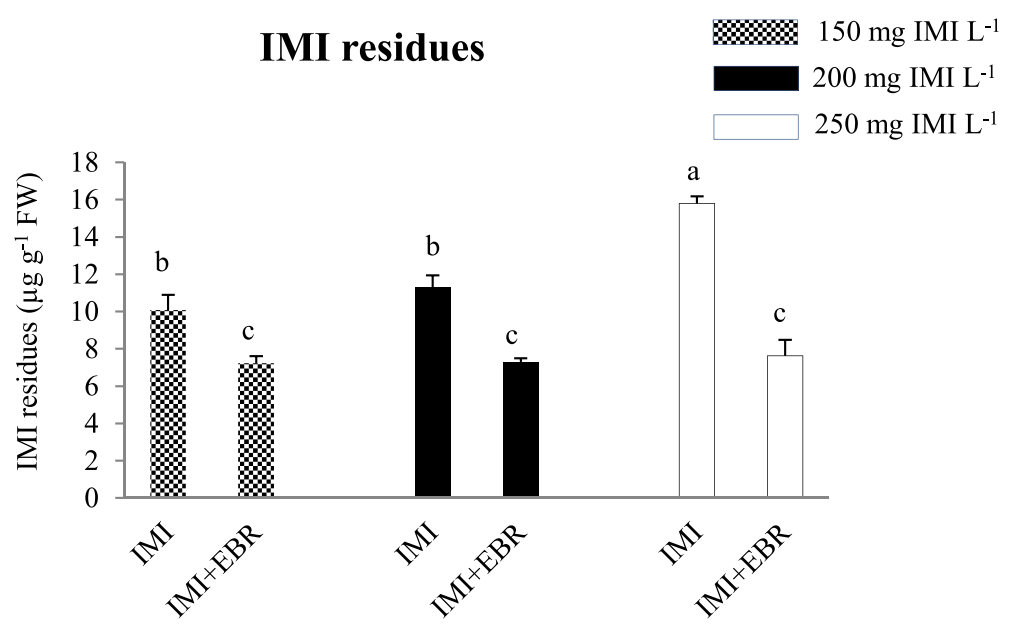

Fig. 2 Effect of EBR seed-soaking on the IMI residues in B. juncea seedlings. Data are shown as the mean \pm standard deviation (three biological replicates), bars with the same letters indicate no significant difference at $p<0.05$. (EBR concentration $=100 \mathrm{nM}$ )

As a result of oxidative stress caused by pesticide toxicity, the antioxidative defense system gets activated in order to efficiently scavenge the ROS and ultimately reduce the oxidative stress [3]. In the current study, the GSH content and the activities of enzymatic antioxidants including SOD, CAT, POD, GR and GST were observed to increase with IMI toxicity (except higher IMI concentration) as well as with the EBR seed application. SOD and CAT are involved in the conversion of harmful superoxide anions to non-toxic water and molecular oxygen. Additionally, it has also been reported that another pathway, the ascorbate-glutathione cycle, is involved in the detoxification of $\mathrm{H}_{2} \mathrm{O}_{2}$ [26]. Glutathione is involved in reduction of $\mathrm{H}_{2} \mathrm{O}_{2}$ into water by the ascorbate-glutathione cycle, which is also catalyzed by the GR enzyme [27]. In the ascorbate-glutathione cycle, GR also plays an important role in reduction of oxidative stress by maintaining the ratio of reduced and oxidized glutathione. In the current study, specific activity of GR was also observed to increase with the application of IMI, which suggests that GR is actively involved in detoxification of ROS generated as a result of IMI toxicity. Similar increase in GR activity was observed in Vigna radiata plants grown under chlorpyrifos toxicity [28].
EBR seed application in the current study further enhanced the activities of all these antioxidative enzymes under IMI toxicity. The alterations of the activities of these antioxidative enzymes might be due to the EBR modulated protein synthesis or altered enzyme kinetics $[29,30]$. Moreover, in the current study, we noticed that gene expression of SOD, CAT, GR, POD and GST1-3,5-6 was also up-regulated in seedlings raised from EBRtreated seeds and grown under IMI toxicity. This suggests that the increase in the expression of the genes encoding these antioxidative enzymes might be one of the reasons for enhanced specific activities of antioxidative enzymes in $B$. juncea plants grown from EBRtreated seeds and grown under IMI stress.

In the current study, IMI residues were observed to decrease in seedlings raised from EBR-treated seeds and grown under IMI toxicity. As described in the introduction section, the three phased enzyme-mediated detoxification system is responsible for pesticide degradation in plants $[7,8]$. In the current study, activities of POD and GST enzymes, which are involved in three phased pesticide detoxification system, were observed to increase with the IMI application as well as EBR seed treatment. Additionally, the gene expression of phase-1 enzyme

Table 4 Two-way ANOVA and multiple linear regression analysis (MLR) of the IMI residues in Brassica juncea seedlings raised from EBR-soaked seeds and grown in IMI supplemented substratum

\begin{tabular}{lllll}
\hline Parameter & F-ratios & & HSD $(p<0.05)$ \\
\cline { 2 - 4 } & $F_{\text {IMI }}$ & $F_{\text {EBR }}$ & $F_{\text {IMIXEBR }}$ & \\
\hline IMI residues & $44.21^{* * *}$ & $322.65^{* * *}$ & $33.31^{* * *}$ & 1.62 \\
MLR equation & & $\beta$-regression coefficients & Multiple correlation coefficient \\
IMI residues $=6.2997+0.0305 X_{1}-0.0500 X_{2}$ & $\beta_{\text {IMI }}$ & $\beta_{\text {EBR }}$ & $0.9062^{* * *}$ \\
\hline
\end{tabular}

$\mathrm{X}_{1}=\mathrm{IMI}\left(\mathrm{mg} \mathrm{L}^{-1}\right), X_{2}=\mathrm{EBR}(\mathrm{nM}),{ }^{* * *}=$ significant at $p<0.001$ 
Table 5 Data showing correlation coefficients obtained from artificial neural networks model

\begin{tabular}{|c|c|c|c|}
\hline \multirow[t]{2}{*}{ Parameter } & \multicolumn{3}{|c|}{ Correlation coefficient } \\
\hline & Train & Test & Validation \\
\hline SOD expression & $0.9255^{* * *}$ & $0.9990^{* * *}$ & $0.9178^{* * *}$ \\
\hline CAT expression & $0.8995^{* * *}$ & $0.9681^{* * *}$ & $0.9940^{* * *}$ \\
\hline POD expression & $0.9231^{* * *}$ & $0.9999^{* * *}$ & $0.9546^{* * *}$ \\
\hline GST-1 expression & $0.9629^{* * *}$ & $0.9987^{* * *}$ & $0.9999^{* * *}$ \\
\hline GST-2 expression & $0.9274^{* * *}$ & $0.7158^{* * *}$ & $0.9653^{* * *}$ \\
\hline GST-3 expression & $0.9632^{* * *}$ & $0.9866^{* * *}$ & $0.9629^{* * *}$ \\
\hline GST-4 expression & $0.9688^{* * *}$ & $0.9993^{* * *}$ & $0.9904^{* * *}$ \\
\hline GST-5 expression & $0.7949^{* * *}$ & $0.4758^{* *}$ & $0.9498^{* * *}$ \\
\hline GST-6 expression & $0.9696^{* * *}$ & $0.9988^{* * *}$ & $0.9976^{* * *}$ \\
\hline GR expression & $0.9769^{* * *}$ & $0.9936^{* * *}$ & $0.9835^{* * *}$ \\
\hline CXE expression & $0.9833^{* * *}$ & $0.9868^{* * *}$ & $0.9846^{* * *}$ \\
\hline P450 expression & $0.9421^{* * *}$ & $0.9603^{* * *}$ & $0.9873^{* * *}$ \\
\hline NADH expression & $0.9593^{* * *}$ & $0.9992^{* * *}$ & $0.9243^{* * *}$ \\
\hline RBO expression & $0.9469 * * *$ & $0.9966^{* * *}$ & $0.9997^{* * *}$ \\
\hline GSH-T expression & $0.9555^{* * *}$ & $0.9984^{* * *}$ & $0.9295^{* * *}$ \\
\hline GSH-S expression & $0.8435^{* * *}$ & $0.9260^{* * *}$ & $0.9822^{* * *}$ \\
\hline $\mathrm{H}_{2} \mathrm{O}_{2}$ content & $0.9053^{* * *}$ & $0.8859^{* * *}$ & $0.9317^{* * *}$ \\
\hline $\mathrm{O}_{2}^{-}$content & $0.9017^{* * *}$ & $0.9784^{* * *}$ & $0.9379 * * *$ \\
\hline GSH content & $0.8829^{* * *}$ & $0.8760^{* * *}$ & $0.9166^{* * *}$ \\
\hline SOD activity & $0.8899 * * *$ & $0.9082^{* * *}$ & $0.9565^{* * *}$ \\
\hline CAT activity & $0.9193^{* * *}$ & $0.9275^{* * *}$ & $0.9615^{* * *}$ \\
\hline POD activity & $0.8475^{* * *}$ & $0.9081^{* * *}$ & $0.8491^{* * *}$ \\
\hline GST activity & $0.9396^{* * *}$ & $0.9401^{* * *}$ & $0.9090^{* * *}$ \\
\hline GR activity & $0.9235^{* * *}$ & $0.9269^{* * *}$ & $0.9573^{* * *}$ \\
\hline IMI residues & $0.9890^{* * *}$ & $0.9809^{* * *}$ & $0.9766^{* * *}$ \\
\hline
\end{tabular}

** and ${ }^{* * *}=$ significant at $p<0.01$ and $p<0.001$ respectively

viz., P450, POD, CXE and phase-2 enzyme GST along with the GSH-S and GSH-T was also observed to increase with EBR application under IMI toxicity. Oxidoreductase helps in pesticide detoxification [4] and the gene expression of $N A D H$ was also noticed to enhance after EBR seed application under IMI toxicity. Since the expression of genes (encoding enzymes involved in pesticide detoxification system) was modulated by EBRseed soaking, this could be the possible reason for the reduction of IMI residues in B. juncea seedlings raised from EBR-treated seeds and grown under IMI toxicity.

\section{Conclusions}

The current study demonstrates that seed soaking with EBR enhances IMI detoxification and decreases oxidative stress in $B$. juncea seedlings through the up-regulation of SOD, CAT, GR, POD, NADH, CXE, GSH-S, GSH-T, $P 450$ and GST1-3,5-6 genes involved in enzymatic pesticide detoxification accompanied by down-regulation of
$R B O$ gene. As compared to earlier studies that were based on foliar application of BRs, the important point in the current study is that a single application of EBR via seed treatment can efficiently activate the plant defence system against pesticide stress by modulation of gene expression.

\section{Abbreviations}

ANOVA: Analysis of variance; AOAC: Association of official analytical chemists; cDNA: Complimentary deoxyribonucleic acid; EBR: 24-epibrassionolide;

EMBL: European molecular biology laboratory; FW: Fresh weight; HSD: Honestly significant difference; MLR: Multiple linear regression; PCR: Polymerase chain reaction; PSA: Primary secondary amine; RNA: Ribonucleic acid

\section{Acknowledgements}

The authors express their sincere gratitude to Department of Science and Technology, Govt. of India for providing INSPIRE fellowship to AS, and to the University Grants Commission, New Delhi for providing sophisticated instrumentation facilities. Thanks to Axios Review, two anonymous reviewers and their editor who provided valuable comments on an earlier version of this manuscript.

\section{Funding}

Not applicable.

\section{Availability of data and materials}

All data generated or analysed during this study are included in this published article.

\section{Author's contributions}

AS, ST and VK performed the experiments. AS and AKT statistically analysed the data and wrote the manuscript. RB, AKT and AKK designed the experiment, supervised the work and critically checked the manuscript. All authors read and approved the final manuscript.

\section{Competing interests}

The authors declare that they have no competing interests.

\section{Consent for publication}

Not applicable.

Ethics approval and consent to participate Not applicable.

\section{Author details}

${ }^{1}$ Plant Stress Physiology Lab, Department of Botanical and Environmental Sciences, Guru Nanak Dev University, Amritsar, India143005. 'Department of Molecular Biology and Biochemistry, Guru Nanak Dev University, Amritsar, India143005.

Received: 1 October 2016 Accepted: 21 February 2017

Published online: 28 February 2017

\section{References}

1. Rajendran S. Environment and health aspects of pesticides use in Indian agriculture. In: Martin J, Bunch V, Suresh M, Kumaran TV, editors. Proceedings of the third international conference on environment and health. Department of Geography, University of Madras and Faculty of Environmental Studies, York University; 2003. p. 353-373.

2. Bonmatin JM, Marchand PA, Charvet R, Moineau I, Bengsch ER, et al. Quantification of imidacloprid uptake in maize crops. J Agric Food Chem. 2005:53:5336-41.

3. Sharma I, Bhardwaj R, Pati PK. Exogenous application of 28homobrassinolide modulates the dynamics of salt and pesticides induced stress responses in an elite rice variety Pusa Basmati-1. J Plant Growth Regul. 2015:34:509-18.

4. Zhou Y, Xia X, Yu G, Wang J, Wu J, et al. Brassinosteroids play a critical role in the regulation of pesticide metabolism in crop plants. Sci Rep. 2015;5: 9018. doi:10.1038/srep09018. 
5. Xia XJ, Zhang Y, Wu JX, Wang JT, Zhou YH, et al. Brassinosteroids promote metabolism of pesticides in cucumber. J Agric Food Chem. 2009;57:8406-13.

6. Cresswell JE. A meta-analysis of experiments testing the effects of a neonicotinoid insecticide (imidacloprid) on honey bees. Ecotoxicol. 2011;20: 149-57.

7. Coleman J, Blake-Kalff M, Davies E. Detoxification of xenobiotics by plants: chemical modification and vacuolar compartmentation. Trends Plant Sci. 1997:2:144-51.

8. Cherian S, Oliveira MM. Transgenic plants in phytoremediation: recent advances and new possibilities. Environ Sci Technol. 2005;39:9377-90.

9. Krishna P. Brassinosteroid-mediated stress responses. J Plant Growth Regul. 2003;22:289-97.

10. Kanwar MK, Poonam, Bhardwaj R. Arsenic induced modulation of antioxidative defense system and brassinosteroids in Brassica juncea L. Ecotoxicol Environ Saf. 2015:115:119-25.

11. Sharma A, Kumar V, Singh R, Thukral AK, Bhardwaj R. Effect of seed pre-soaking with 24-epibrassinolide on growth and photosynthetic parameters of Brassica juncea L. in imidacloprid soil. Ecotoxicol Environ Saf. 2016;133:195-201.

12. Sharma A, Kumar V, Thukral AK, Bhardwaj R. Epibrassinolide-imidacloprid interaction enhances non-enzymatic antioxidants in Brassica juncea L. Ind J Plant Physiol. 2016;21:70-5.

13. Wu GL, Cui J, Tao L, Yang H. Fluroxypyr triggers oxidative damage by producing superoxide and hydrogen peroxide in rice (Oryza sativa). Ecotoxicol. 2010;19:124-32.

14. Patterson BD, Mackae EA, Mackae I. Estimation of hydrogen peroxide in plants extracts using titanium (iv). Anal Biochem. 1984;139:487-92.

15. Kono Y. Generation of superoxide radical during auto oxidation of hydroxylamine and an assay for superoxide dismutase. Arch Biochem Biophy. 1978;186:189-95.

16. Aebi H. Catalase in vitro. Methods Enzymol. 1984;105:121-6.

17. Putter J. Peroxidases. In: Bergmeyer HU, editor. Methods of enzymatic analysis. New York: Verlag Chemie-Academic Press; 1974. p. 685-90.

18. Carlberg I, Mannervik B. Purification and characterization of the flavoenzyme glutathione reductase from rat liver. J Biol Chem. 1975;250:5475-80.

19. Habig WH, Jakoby WB. Glutathione S-transferases (rat and human). Methods Enzymol. 1981;77:218-31.

20. Sedlak J, Lindsay RHC. Estimation of total, protein bound and non protein sulfhydryl groups in tissue with Ellmann's reagent. Anal Biochem. 1968;25:192-205.

21. Livak KJ, Schmittgen TD. Analysis of relative gene expression data using real-time quantitative PCR and the $2^{-\Delta \Delta C T}$ method. Methods. 2001;25:402-8.

22. AOAC Official Method 2007.01. Pesticide residues in foods by acetonitrile extraction and partitioning with magnesium sulfate, gas chromatography/ mass spectrometry and liquid chromatography/tandem mass spectrometry. AOAC Int. 2007.

23. Mittler R. Oxidative stress, antioxidants and stress tolerance. Trends Plant Sci. 2002:7:405-10

24. Hayat S, Khalique G, Wani AS, Alyemeni MN, Ahmad A. Protection of growth in response to 28-homobrassinolide under the stress of cadmium and salinity in wheat. Int J Biol Macromol. 2014;64:130-6.

25. Fariduddin Q, Yusuf M, Ahmad I, Ahmad M. Brassinosteroids and their role in response of plants to abiotic stresses. Biol Planta. 2014;58:9-17.

26. Asada K, Takahash M. Production and scavenging of active oxygen in photosynthesis. In: Kyle DJ, Osmond CB, Arntzen CJ, editors. Photoinhibition. Amsterdam: Elsevier; 1987. p. 227-87.

27. Chew O, Whelan J, Millar AH. Molecular definition of the AscorbateGlutathione cycle in Arabidopsis mitochondria reveals dual targeting of antioxidant defenses in plants. J Biol Chem. 2003:47:46869-77.

28. Parween T, Jan S. Mahmooduzzafar, Fatma T. Evaluation of oxidative stress in Vigna radiata L. in response to chlorpyrifos. Int J Environ Sci Technol. 2012;9:605-12

29. Lascano HR, Gomez LD, Casano LM, Trippi VS. Changes in glutathione reductase activity and protein content in wheat leaves and chloroplasts exposed to photooxidative stress. Plant Physiol Biochem. 1998;36:321-9.

30. Thao NP, Tran LS. Potentials toward genetic engineering of drought tolerant soybean. Crit Rev Biotechnol. 2012;32:349-62.

\section{Submit your next manuscript to BioMed Central and we will help you at every step:}

- We accept pre-submission inquiries

- Our selector tool helps you to find the most relevant journal

- We provide round the clock customer support

- Convenient online submission

- Thorough peer review

- Inclusion in PubMed and all major indexing services

- Maximum visibility for your research

Submit your manuscript at www.biomedcentral.com/submit
Biomed Central 